\title{
Ellipsis
}

Volume 45

Article 16

2018

\section{Touch and Go}

Betsy Housten

University of New Orleans

Follow this and additional works at: https://scholarworks.uno.edu/ellipsis

\section{Recommended Citation}

Housten, Betsy (2018) "Touch and Go," Ellipsis: Vol. 45 , Article 16.

DOI: https://doi.org/10.46428/ejail.45.16

Available at: https://scholarworks.uno.edu/ellipsis/vol45/iss1/16

This Poetry is brought to you for free and open access by the Department of English and Foreign Languages at ScholarWorks@UNO. It has been accepted for inclusion in Ellipsis by an authorized editor of ScholarWorks@UNO.

For more information, please contact scholarworks@uno.edu. 


\section{BETSY HOUSTEN}

\section{Touch and Go}

Winner of the Andrea Saunders Gereighty Award

Maybe you felt the crash splinter your bones like a hammer into drywall, saw a blind headlight scrape the maple tree before the Buick broke it. Maybe your hands braced against the seat back while your skull smashed the overhead light.

Every summer my mother told me the story: June 6, 1964, your blood on the ceiling, encephalitis on a doctor's tongue. Four years from seat belt laws. The year she turned fourteen, your littlest sister, crying in the ICU. Maybe you pictured the boys from the car while you wrestled the coma: Walker hanging out the window, Jimbo in the back next to you, Manara at the wheel, breath warm with beer. Touch and go, said your nurse. Three days later, your pulse quit fighting.

December 10, 2017: a man turned his car into the bike lane without looking. I could not stop him, could only holler as he collided with my bicycle, then clatter to the asphalt elbow first, bones stacked by split-second instinct, helmet cracking on the tar. The road tore two layers of clothes, dug its bloody teeth into my arm. I wrenched my body up as the man pulled over, traffic stopped on all sides of us, the day holding its breath, and when I reached his window a fury shot from my throat: first my own terror, but then it kept going, roaring out of a deep place, an old place, ancestral marrow remembering how a young girl sobbed in a hospital room before I was born, hoping against hope. 